\title{
A Mini-Review on the Phytochemistry and Biological Activities of Selected
}

\section{Apocynaceae Plants}

\section{Running Title: Biological Activities of Selected Apocynaceae Plants}

Abiche Ekalu ${ }^{a^{*}}$ ORCID ID: 0000-0003-3343-1491), Rachael Gbekele-Oluwa Ayo ${ }^{\mathrm{b}}$, James Dama Habila $^{\text {b }}$ Ibrahim Hamisu ${ }^{\text {b }}$

${ }^{\mathrm{b}}$ Department of Chemistry, Ahmadu Bello University Zaria, Kaduna, Nigeria Corresponding author address: Department of Chemistry, Nigerian Army School of Education, Ilorin, Kwara, Nigeria

Email: ekalumiracle@gmail.com

Keywords: phytochemistry, biological activities, Apocynaceae family

\begin{abstract}
This review aims at studying the phytochemistry and biological activities of some selected Apocynaceae plants. Eleven members of this family were reviewed for their phytochemistry and biological activities. Interestingly, the commonly isolated compounds reported from Mondia whitei (Hook.f.) Skeels, Secondatia floribunda A. DC, Carissa carandas, Tabernaemontana divaricate, Nerium oleander, Wrightia tinctoria, T. divaricate, Alstonia scholaris, Carrisa spinarum Linn, Thevetia peruviana and Caralluma lasiantha were triterpenoids, flavonoids, phytosterols, cardiac glycosides and lignans. All of them exhibited remarkable biological activities, mostly similar to each other. This review provides a detailed insight into the pharmacological activities of these selected members of this family.
\end{abstract}

\section{Implication for health policy/practice/research/medical education:}


This review showed that selected Apocynaceae plants can be used as potential source of treatment for various ailments in developing countries.

\section{Introduction}

The plants used for medicinal purposes are known to be potential sources of therapeutics and play important role in our daily life $(1,2)$. In developing nations, medicinal plants are used as alternative source of treatments (3) whereby the extracts and phytochemicals isolated from them have shown in vitro and in vivo biological activities (4).

Mankind has used herbal products to treat pains and to even cure different forms of ailments (4) for the past 60,000 years (5). Presently, over $50 \%$ of natural drugs that are being used for medication, are derived from plants $(5,6)$.

The World Health Organization (WHO) has reviewed that about $80 \%$ of the population all over the world use herbs to treat various ailments (7) as well as for their other healthcare needs (2).

Herbals are natural products that have been found to be safe because of the limited side-effects. Apart from the medicinal uses of these herbals, they are also used as dietary supplements assisting the human body as defensive mechanism against these diseases. These days, herbal products are being sold in powder form, tablets, capsules and tea extracts (4). Traditionally, herbal products are seen to be harmless to people; they do not hesitate to take them without any prescription and in any dosage. However, some of these plats may be toxic and can cause grave health problems. However, some that are taken may not be effective and some may even interact with other drugs used. Assessing the quality and standard of these herbal products is very important so as to determine the bioactive ingredients that confers on them these huge medicinal potentials (8). This review provides s detailed insight into the pharmacological activities of these selected members of this family.

\section{The Apocynaceae family}

Apocynaceae family (also called the dogbane family) includes flowering plants which are made up of herbs, shrubs, trees, stem succulents and vines (5). The origin of members of this family were traced to the Europe, Asia, Africa, Australia, and American tropics or subtropics, with 
some temperate members (9). The former family called Asclepiadaceae (and now Asclepiadoideae) is considered to be a subfamily of the Apocynaceae which contains 348 genera (10). Many of these species are mainly the tall trees found in tropical forests. However, some members grow in tropical dry areas while some members are perennial herbs found in temperate zones (5). Many of these plants are known to have milky latex while some species of the family are known to be poisonous if ingested. For instance, Adenium a genera of the Apocynaceae family have been reported to have a milky latex while Pachypodium have only clear sap without latex (3).

Major characteristic features of this family are that almost all species are known to produce milky sap (10). Ethnomedicinally, the Apocynaceae family is being used to treat malaria, gastrointestinal ailments, fever, pain and diabetes as well as skin infections (10). Some of the Apocynaceae plants have been reported for the anticancer and antimalarial properties (1). This family is known as one of the largest and useful families in angiosperm (6). Because of the huge medicinal values of this family, many of them have been used in the treatment of various ailments (11). They are also consumed by many tribes as food and used as poisons (1). The Apocynaceae plants are reported to be rich in triterpenoids, flavonoids, alkaloids, steroids, glycosides, phenols and lactones, $(4,11)$. Phytochemicals like sugars, sterols and lignans as well as lactones have been reported in this family (4). Antimicrobial, anti-inflammatory, antioxidant and cytotoxic activities of crude extracts and the compounds isolated from various members of the Apocynaceae family have been reported $(6,11)$. 
Table 1: Summary of phytochemical and pharmacological activities of selected Apocynaceae plants

\begin{tabular}{|c|c|c|c|c|}
\hline No. & Plant source & Phytochemicals & Biological activity & References \\
\hline 1 & $\begin{array}{l}\text { Mondia whitei } \\
\text { (Hook.f.) Skeels }\end{array}$ & $\begin{array}{l}\text { Propacin, coumarinolignan, 5-cloropropacin, (-)-loliolide, } \\
\text { 2-hydroxy-4-methoxybenzaldehyde and isovanilin, 2- } \\
\text { hydroxy-4-methoxybenzaldehyde and 3-hydroxy-4- } \\
\text { methoxybenzatdehyde (isovanillin) }\end{array}$ & $\begin{array}{l}\text { Anti-inflammatory, aphrodisiac, } \\
\text { antimicrobial, anti-tyrosinase and } \\
\text { antioxidant activity. }\end{array}$ & $(8,11)(12)(13)$ \\
\hline 2 & $\begin{array}{l}\text { Secondatia } \\
\text { floribunda A. } \\
\text { DC }\end{array}$ & $\begin{array}{l}\text { gallic acid, cafeic acid, cianidin, apigenin, catechin and } \\
\text { quercetin. }\end{array}$ & $\begin{array}{l}\text { Antibacterial activity clinically } \\
\text { significant against strains of } \\
\text { Staphylococcus aureus and Escherichia } \\
\text { coli. }\end{array}$ & (7) \\
\hline 3 & $\begin{array}{l}\text { Carissa } \\
\text { carandas }\end{array}$ & $\begin{array}{l}\text { Rutin, epicatechin, quercetin, and kaempferol, Sitosterol } \\
\text { glucoside, Triterpenoids, lupeol, betulinic acid, oleanolic } \\
\text { acid, } \alpha \text {-amyrin and } \beta \text {-amyrin, Oleanolic acid, carinol, } \\
\text { carissanol, and (-)-nortrachelogenin. }\end{array}$ & $\begin{array}{l}\text { Flavonoids exhibited anti-inflammatory } \\
\text { activity against croton oil-induced } \\
\text { edema in an albino mouse model with } \\
\mathrm{IC}_{50} \text { of } 500 \mu \mathrm{g} / \mathrm{ml} \text {. Stigmasterol } \\
\text { exhibited marked anti-inflammatory } \\
\text { activity. The compounds exhibited anti- } \\
\text { inflammatory activity against } \\
\text { proinflammatory mediators such as } \\
\text { nitric oxide (NO), tumor necrosis } \\
\text { factor- } \alpha \text {, and interlukin-1b. Exhibited } \\
\text { anti-tumor activity, anti-plasmodial } \\
\text { activity against the chloroquin-senitive }\end{array}$ & $\begin{array}{l}(11)(14)(15) \\
(16) \\
(17)(18)(4)(9)\end{array}$ \\
\hline
\end{tabular}




\begin{tabular}{|c|c|c|c|c|}
\hline & & & $\begin{array}{l}\text { (D6) strains of plasmodium falciparum } \\
\text { parasite with IC50 value of } 1.95 \\
\text { Dg/ml. }\end{array}$ & \\
\hline 4 & $\begin{array}{l}\text { Tabernaemonta } \\
\text { na divaricata }\end{array}$ & Calycosin and formononetin. & $\begin{array}{l}\text { These flavonoids exhibited anti- } \\
\text { inflammatory activity against croton } \\
\text { oil-induced edema in an albino mouse } \\
\text { model with } \mathrm{IC}_{50} \text { of } 500 \mu \mathrm{g} / \mathrm{ml} \text {. }\end{array}$ & $(11)(4)$ \\
\hline 5 & $\begin{array}{l}\text { Nerium } \\
\text { oleander }\end{array}$ & oleandric acid and kaneroside. & $\begin{array}{l}\text { Exhibited anti-inflammatory and } \\
\text { anticancer activity. }\end{array}$ & (11) \\
\hline 6 & $\begin{array}{l}\text { Wrightia } \\
\text { tinctoria }\end{array}$ & $\begin{array}{l}\text { wrightial and lupeol, stigmasterol, } \beta \text {-sitosterol, } \\
\text { campesterol, phytosterol and lanosterol. }\end{array}$ & $\begin{array}{l}\text { These triterpenoids exhibited } \\
\text { antimicrobial, anti-inflammatory, and } \\
\text { antitumor activity. Exhibited } \\
\text { hepatoprotective, anti-inflammatory, } \\
\text { and antihyperlipidemic activities }\end{array}$ & $(15)(11)(4)$ \\
\hline 7 & T. divaricata & Taraxasterol acetate. & $\begin{array}{l}\text { Exhibited antimicrobial, anti- } \\
\text { inflammatory, and antitumor activity. }\end{array}$ & $(11)(4)$ \\
\hline 8 & $\begin{array}{l}\text { Alstonia } \\
\text { scholaris. }\end{array}$ & $\begin{array}{l}\text { Alstonic acids and oleanolic acid, stigmasterol, } \beta- \\
\text { sitosterol, and campesterol. }\end{array}$ & $\begin{array}{l}\text { These triterpenoids exhibited } \\
\text { antimicrobial, anti-inflammatory, and } \\
\text { antitumor activity. Exhibited } \\
\text { hepatoprotective, anti-inflammatory, } \\
\text { and antihyperlipidemic activities }\end{array}$ & $(11)(4)$ \\
\hline
\end{tabular}




\begin{tabular}{|c|c|c|c|c|}
\hline 9 & spinarum Linn & odoroside and evomoside. & $\begin{array}{l}\text { Exhibited antimicrobial, anti- } \\
\text { inflammatory, and antitumor activity. }\end{array}$ & $(19)(20)(4)$ \\
\hline 10 & $\begin{array}{l}\text { Thevetia } \\
\text { peruviana. }\end{array}$ & Thevefolin. & $\begin{array}{l}\text { Thevefolin was reported to be effective } \\
\text { for TRAIL resistance in human gastric } \\
\text { adenocarcinoma cells. }\end{array}$ & $(21)(4)$ \\
\hline 11 & $\begin{array}{l}\text { Caralluma } \\
\text { lasiantha }\end{array}$ & $\begin{array}{l}\text { luteoline-4-O-neohesperiodoside and } 3 \beta, 14 \beta \text {-dihydroxy- } \\
14 \beta \text {-pregn-5-en-20-one. }\end{array}$ & $\begin{array}{l}\text { Exhibited antibacterial activity against } \\
\text { both Gram (-) bacteria and Gram (+) } \\
\text { bacteria }\end{array}$ & $(22)(2,17)$ \\
\hline
\end{tabular}




\subsection{Phytochemistry and biological activities of Apocyanaceae family}

Biological assays have been done on Mondia whitei (Hook.f.) Skeels including antiinflammatory, anti-tyrosinase, antimicrobial, anti-aphrodisiac and antioxidant activities(8). The qualitative phytochemical analysis of ethanol extract of $M$. whitei led to the isolation of propacin , coumarinolignan, 5-cloropropacin, (-)-loliolide, 2-hydroxy-4-methoxybenzaldehyde and isovanilin (12).

A methylene chloride extract of Mondia whitei (Hook.f.) Skeels yielded various compounds including 2-hydroxy-4-methoxybenzaldehyde and 3-hydroxy-4-methoxybenzatdehyde (isovanillin) $(11,23)$.

The phytochemical investigation of the ethanol extract of the stem bark of Secondatia floribunda A. DC (Apocynaceae) showed antibacterial activity clinically significant against strains of Staphylococcus aureus and Escherichia coli (23). The compounds isolated from this extract were gallic acid, cafeic acid, cianidin, apigenin, catechin and quercetin $(7,23)$.

Also, rutin, epicatechin, quercetin and kaempferol were isolated from Carissa carandas fruits as principal flavonoids with the total flavonoid content of $4.8 \mathrm{mg} / 100 \mathrm{~g}$ (1). The root and stem extracts of Tabernaemontana divaricata were also reported to contain novel flavonoids, calycosin and formononetin (1). All of these flavonoids exhibited anti-inflammatory potential against croton oil-induced edema in an albino mouse model with $\mathrm{IC}_{50}$ of $500 \mu \mathrm{g} / \mathrm{ml}(1,11)$.

Triterpenoids, lupeol, betulinic acid, oleanolic acid, $\alpha$-amyrin and $\beta$-amyrin were largely distributed in the leaves, roots, and fruits of the Carissa genus (15). A novel oleandric acid isolated from Nerium oleander exhibited anti-inflammatory and anticancer potential $(4,11)$. Phytochemical investigation of Wrightia tinctoria led to the isolation of a new triterpenoid, wrightial, and known lupeol (4). Taraxasterol acetate was isolated from the roots and stem of $T$. divaricata $(4,11)$. Alstonic acids and oleanolic acid were reported from the leaves of Alstonia scholaris. These triterpenoids exhibited antitumor, antimicrobial and anti-inflammatory activities (15). Oleanolic acid exhibited anti-inflammatory activity against proinflammatory mediators such as nitric oxide (NO), tumor necrosis factor- $\alpha$ (TNF- $\alpha$ ), and interlukin-1b $(4,16)$.

Bioactivities exhibited by phytosterol include anti-inflammatory, hepatoprotective and antihyperlipidemic activities (11). Wrightia tinctoria and Alstonia scholaris contain various kinds of phytosterols such as stigmasterol, $\beta$-sitosterol, and campesterol. Also, uncommon 
sterols, phytosterol and lanosterol were reported from Wrightia tinctoria seeds. Sitosterol glucoside was isolated from Carissa carandas roots. Stigmasterol from Carissa carandas has shown marked anti-inflammatory activity $(4,14)$.

Carinol, carissanol and (-)-nortrachelogenin were isolated from the root extract of Carissa carandas (24).

A cardiac glycoside, kaneroside was isolated from the leaves of Nerium oleander (21). Cardiac glycosides were also isolated from the roots of Carissa carandas (4) and identified as odoroside and evomoside (19). Thevefolin was reported as a cardenolide of Thevetia peruviana. Thevefolin was reported to be effective for TRAIL resistance in human gastric adenocarcinoma cells (21).

Caralluma lasiantha has been studied for its phytochemical potential and the crude extract led to the isolation of luteoline-4-O-neohesperiodoside and 3 $\beta, 14 \beta$-dihydroxy-14 $\beta$-pregn-5-en-20-one which exhibited antibacterial activity against both Gram (-) bacteria and Gram (+) bacteria (Malladi et al., 2017).<smiles>COc1cc([C@H]2Oc3c(OC)cc4ccc(=O)oc4c3O[C@@H]2C)ccc1O</smiles><smiles>CC1(C)C[C@H](O)C[C@@]2(C)OC(=O)C=C12</smiles>

(-)-loliolide<smiles>COc1cc([C@H]2Oc3c(OC)cc4ccc(=O)oc4c3O[C@H]2C)cc(OC)c1O</smiles>

coumarinolignan<smiles>COc1ccc(C=O)c(O)c1</smiles>

2-hydroxy-4-methoxybenzaldehyde<smiles>COc1cc([C@H]2Oc3c(c(Cl)c4ccc(=O)oc4c3OC)O[C@H]2C)ccc1O</smiles>

5-cloropropacin<smiles>COc1ccc(C=O)cc1C</smiles> 
<smiles>COc1ccc(C=O)c(O)c1</smiles>

2-hydroxy-4-methoxybenzaldehyde

(9)<smiles>O=C(O)/C=C/c1ccc(O)c(O)c1</smiles>

cafeic acid<smiles>O=c1cc(-c2ccc(O)cc2)oc2cc(O)cc(O)c12</smiles>

apigenin

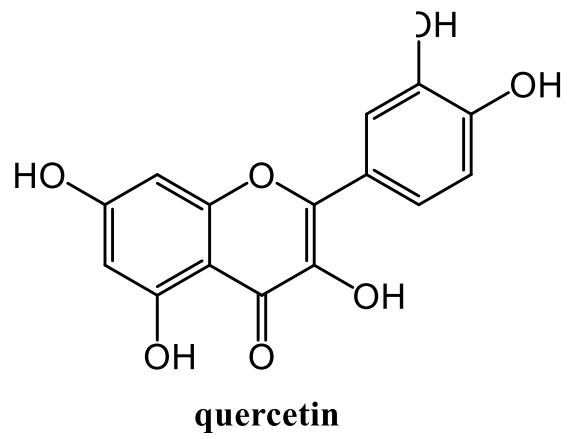<smiles>COc1ccc(C=O)cc1O</smiles>

3-hydroxv-4-methoxybenzatdehyde (isovani<smiles>CC(Cl)(Cl)c1cc(C(=O)O)cc(O)c1O</smiles><smiles>OC1=C(c2ccc(O)c(O)c2)[O+]c2cc(O)cc(O)c2C1</smiles>

$$
\text { cianidin }
$$<smiles>OC1=C(c2ccc(O)c(O)c2)Oc2cc(O)cc(O)c2C1</smiles>

catechin<smiles>O=c1c(OC2OC(OC3OC(C(O)O)[C@@H](O)[C@H](O)C3O)C(O)[C@@H](O)[C@H]2O)c(-c2ccc(O)cc2)oc2cc(O)cc(O)c12</smiles> 
<smiles>[R]c1cc(-c2oc3cc(O)cc(O)c3c(=O)c2O)cc([R])c1O</smiles>

epicatechin, $\mathbf{R}_{1}=\mathbf{O H}$ quercetin, $\mathbf{R}_{\mathbf{1}}=\mathbf{H}$ kaempferol, $\mathbf{R}_{2}=\mathbf{O C H 3}$

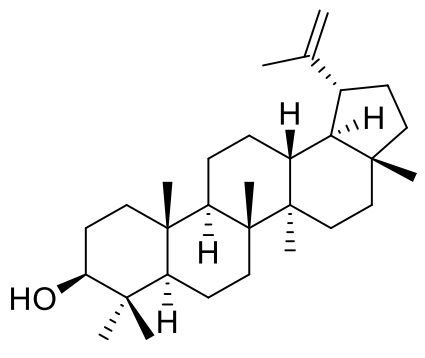
lupeol

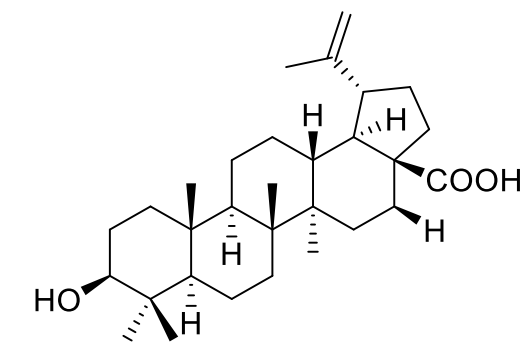

betulinic acid

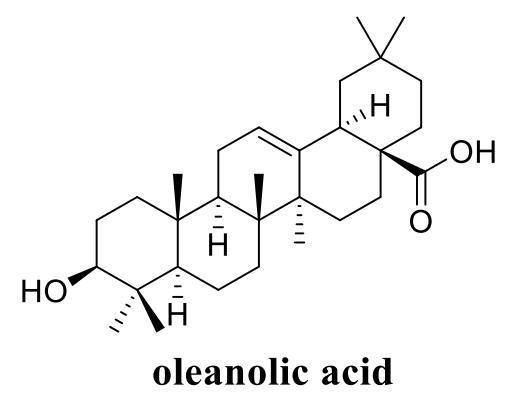

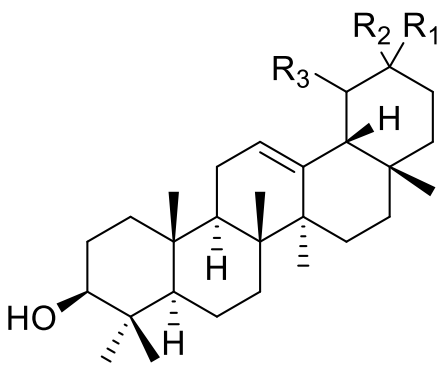

$\alpha-$ amyrin, $\mathbf{R}_{1}=\mathrm{CH}_{3}, \mathbf{R}_{2}=\mathrm{H}, \mathbf{R}_{3}=\mathrm{CH}_{3}$

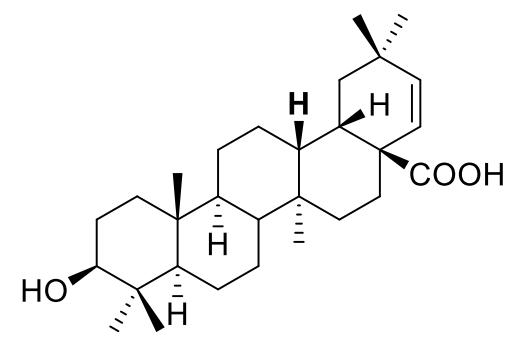

oleandric acid<smiles>COc1ccc(-c2coc3cc(O)ccc3c2=O)cc1</smiles>

formononetin

$\beta$-amyrin, $\mathbf{R}_{1}=\mathrm{CH}_{3}, \mathbf{R}_{2}=\mathrm{CH}_{3}, \mathbf{R}_{3}=\mathrm{H}$<smiles>C[C@H](CCC=O)[C@H]1CC[C@]2(C)[C@@H]3CC[C@H]4C(C)(C)[C@@H](O)CC[C@]4(C)[C@]3(C)CC[C@]12C</smiles>

wrightial

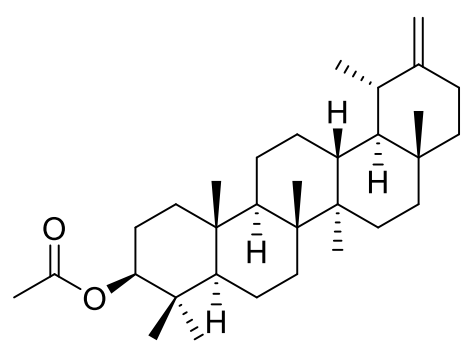

taraxasterol acetate

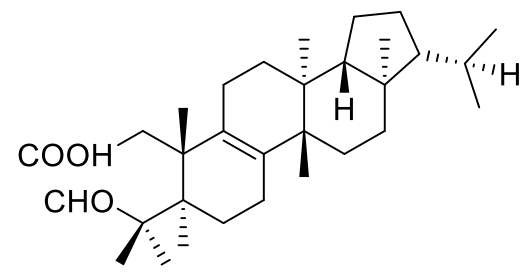

alstonic acids

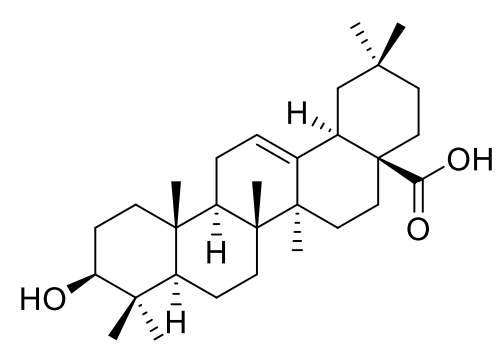

oleanolic acid 


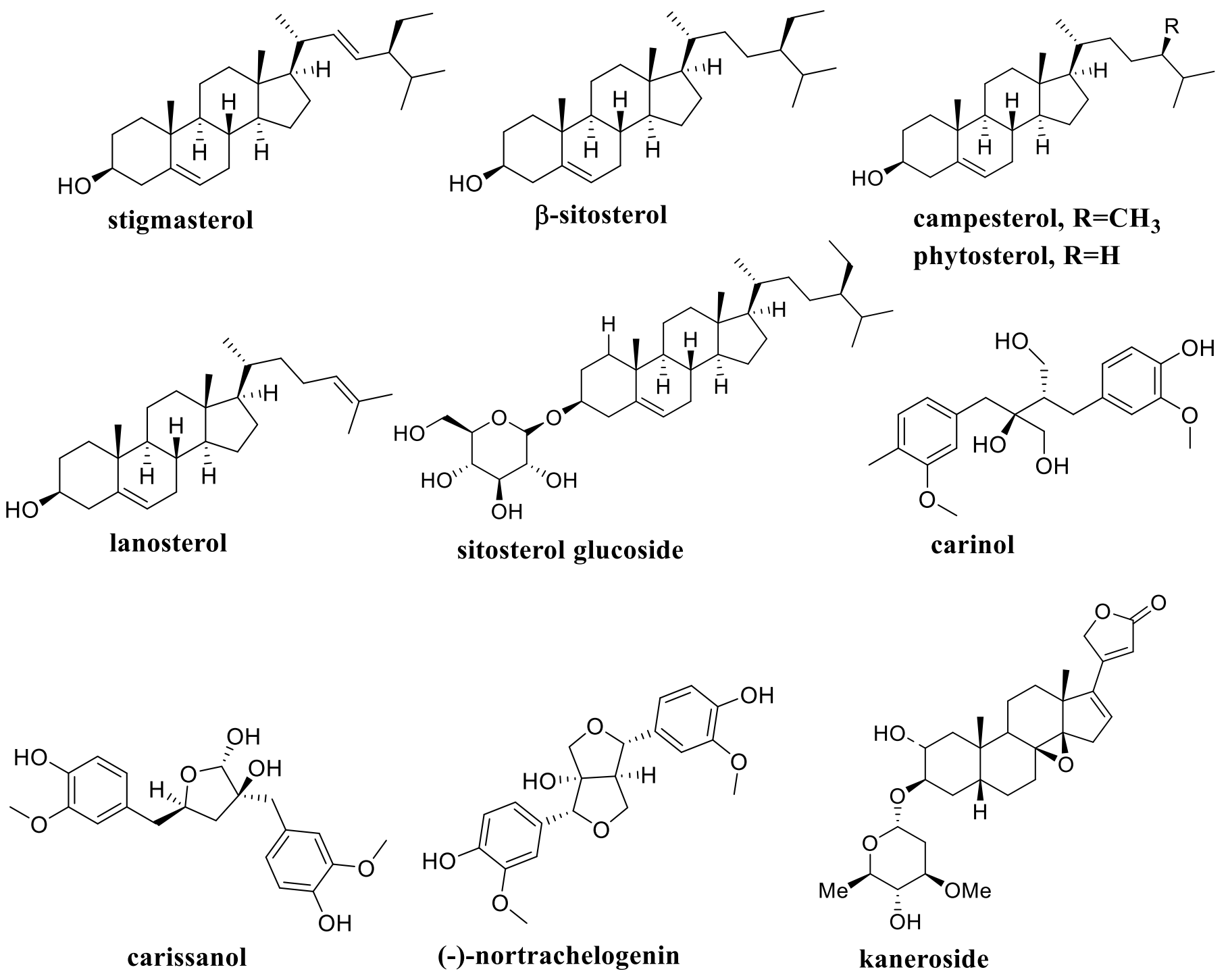




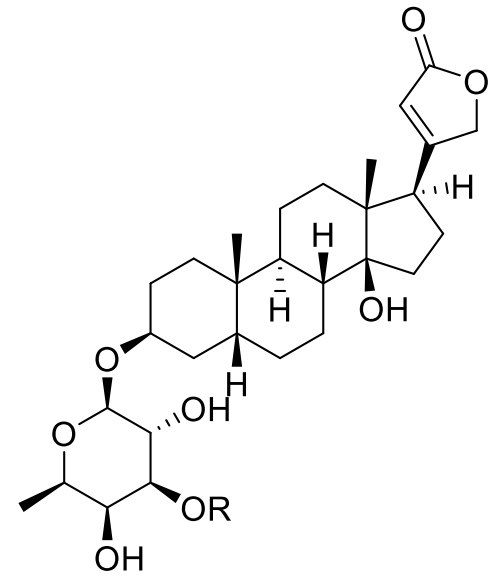

odoroside, $\mathrm{R}=\mathrm{CH3}$

evomoside, $\mathbf{R}=\mathbf{H}$

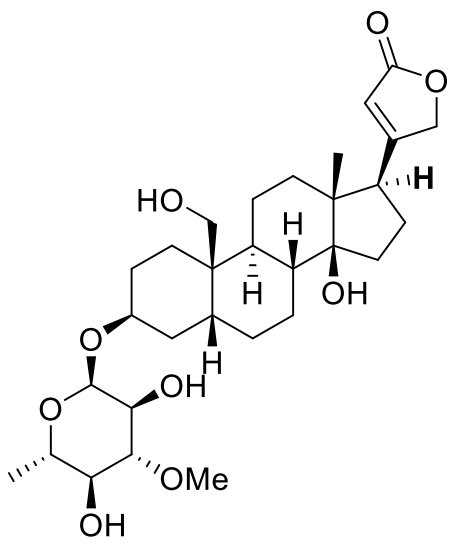

thevefolin

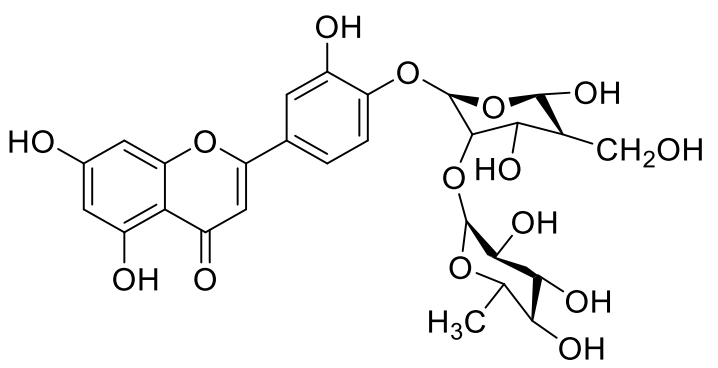

luteoline-4-O-neohesperiodoside<smiles>CC(=O)[C@H]1CC[C@H]2[C@H]3CC=C4C[C@@H](O)CC[C@]4(C)[C@H]3CC[C@]12C</smiles>

$3 \beta, 14 \beta$-dihydroxy-14 $\beta$-pregn-5-en-20-one

Figure 1: chemical structure of some compounds isolated from selected Apocynaceae plants

\section{Conclusion}

The Apocynaceae plants have been reported for its vast medicinal potentials. Consequently, eleven members of the Apocynaceae plants reviewed for phytochemical constituent and biological properties. We discovered that the phytochemicals commonly isolated from these plants were triterpenoids, flavonoids, phytosterols, cardiac glycosides and lignans. These phytochemicals were reported to exhibit similar biological activities. We also noted that all of them possess a wide range of biological properties. We therefore conclude that the ethnomedicinal uses of the Apocynaceae plants in the treatment of various kinds of ailments were due to these bioactive constituents. 


\section{Authors' contributions}

Author AE prepared the manuscript while authors RGA, JDH and HI supervised the research. All authors all contributed equally in planning and carrying out this study. All authors read the manuscript and confirmed the publication for final version.

\section{Conflicts of interest}

No conflicts of interest among the authors.

\section{Ethical considerations}

Ethical issues have been observed by the authors.

\section{Funding/support}

This study receives no funding or grant.

\section{References}

1. Islam MS, Lucky RA. A Study on different plants of Apocynaceae family and their medicinal uses. Universal Journal of Pharmaceutical Research. 2019;4(5):42-6.

2. Samoisy AK, Mahomoodally MF. Ethnopharmacological analysis of medicinal plants used against non-communicable diseases in Rodrigues Island, Indian Ocean. Journal of Ethnopharmacology [Internet]. 2015;173:20-38. Available from: http://dx.doi.org/10.1016/j.jep.2015.06.036

3. Bruyns P V, Klak C, Hanacek P. Recent radiation of Brachystelma and Ceropegia (Apocynaceae) across the old world against a background of climatic change. Molecular Phylogenetics and Evolution [Internet]. 2015;90:49-66. Available from: https://ac.elscdn.com/S1055790315001177/1-s2.0-S1055790315001177-main.pdf?_tid=7a34a5c69892-4e2f-9714c45fcf64de4d\&acdnat=1537972893_ba6d1662e5e3cda4fc65afe034a23737

4. Höfling J, Anibal PC, Obando-Pereda G, A T Peixoto I, Furletti VF, Foglio M, et al. Antimicrobial potential of some plant extracts against Candida species. Brazilian Journal of Biology [Internet]. 2010;70:1065-8. Available from: http://www.scielo.br/pdf/bjb/v70n4/a22v70n4.pdf

5. Fabricant DS, Farnsworth NR. The value of plants used in traditional medicine for drug discovery. Environ Health Perspect [Internet]. 2001/03/17. 2001;109 Suppl:69-75. Available from: https:/www.ncbi.nlm.nih.gov/pmc/articles/PMC1240543/pdf/ehp109s000069.pdf

6. Yarnell E, Abascal K. Overview of Drug-Herb Interactions. Vol. 8, Alternative and Complementary Therapies. Alternative and Complementary Therapies: Alternative and Complementary Therapies; 2002. 87-96 p.

7. Ribeiro DA, Damasceno SS, Boligon AA, de Menezes IRA, Souza MM de A, da Costa JGM. Chemical profile and antimicrobial activity of Secondatia floribunda A. DC 
(Apocynaceae). Asian Pacific Journal of Tropical Biomedicine [Internet]. 2017;7(8):73949. Available from: http://www.sciencedirect.com/science/article/pii/S2221169117307724

8. Yadav NP, Thakur M, Dixit VK. Recent Approaches in Herbal Drug Standardization. Govil JN, Singh VK, editors. International Journal of Integrative Biology. 2009;24:25-44.

9. Bruyns P V, Klak C, Hanacek P. A revised, phylogenetically-based concept of Ceropegia (Apocynaceae) (vol 112, pg 399, 2017). South African Journal of Botany [Internet]. 2018;116:140-1. Available from: https://ac.els-cdn.com/S0254629917316320/1-s2.0S0254629917316320-main.pdf?_tid=72f21cd7-a38b-4180-af194be475b275cd\&acdnat=1538406589_a933003e6cf2e1eed83d4a0f9fba60b9

10. Nazar N, Goyder DJ, Clarkson JJ, Mahmood T, Chase MW. The taxonomy and systematics of Apocynaceae: where we stand in 2012. Botanical Journal of the Linnean Society [Internet]. 2013;171(3):482-90. Available from: https://dx.doi.org/10.1111/boj.12005

11. Bhadane BS, Patil MP, Maheshwari VL, Patil RH. Ethnopharmacology, phytochemistry, and biotechnological advances of family Apocynaceae: A review. Phytotherapy Research [Internet]. 2018;32(7):1181-210. Available from: https://onlinelibrary.wiley.com/doi/pdf/10.1002/ptr.6066

12. Aremu AO, Cheesman L, Finnie JF, Van Staden J. Mondia whitei (Apocynaceae): A review of its biological activities, conservation strategies and economic potential. South African Journal of Botany [Internet]. 2011;77(4):960-71. Available from: http://www.sciencedirect.com/science/article/pii/S0254629911001001

13. Koorbanally NA, Mulholland DA, Crouch NR. Isolation of Isovanillin from Aromatic Roots of the Medicinal African Liane, Mondia whitei. Journal of Herbs, Spices \& Medicinal Plants [Internet]. 2000 Dec 18 [cited 2019 Feb 18];7(3):37-43. Available from: http://www.tandfonline.com/doi/abs/10.1300/J044v07n03_05

14. Ahmed D, Fatima K, Saeed R, Masih R. Isolation and identification of bioactive compounds from chloroform fraction of methanolic extract of Carissa opaca roots. Natural Product Research [Internet]. 2016;30(17):2012-6. Available from: https://doi.org/10.1080/14786419.2015.1107058

15. Singh DA, Uppal DGK. A review on Carissa carandas. Asian Journal of Pharmaceutical and Clinical Research [Internet]. 2015th-5th-1st ed. 2015;8(3):26-30. Available from: https://innovareacademics.in/journals/index.php/ajpcr/article/view/5527

16. Itankar PR, Lokhande SJ, Verma PR, Arora SK, Sahu RA, Patil AT. Antidiabetic potential of unripe Carissa carandas Linn. fruit extract. Journal of Ethnopharmacology [Internet]. 2011/03/29. 2011;135(2):430-3. Available from: https://ac.elscdn.com/S0378874111001723/1-s2.0-S0378874111001723-main.pdf?_tid=a49ecdecb6ee-49a2-b8deda0209f58c0b\&acdnat=1548074830_7f090a0712d0e5aec4cd2b67e2118e82

17. Kaunda JS, Zhang Y-J. The Genus Carissa: An Ethnopharmacological, Phytochemical and Pharmacological Review. Natural Products and Bioprospecting [Internet]. 2017;7(2):18199. Available from: https://doi.org/10.1007/s13659-017-0123-0 
18. Wangteeraprasert R, Lipipun V, Gunaratnam M, Neidle S, Gibbons S, Likhitwitayawuid K. Bioactive compounds from Carissa spinarum. Phytotherapy Research. 2012;26(10):1496-9.

19. Hegde K, Satyanarayana D, Joshi AB. Phytochemical investigation of root extract of the plant Carissa spinarum. J Pharm Sci Res. 2012;2(1):55-59, 5 pp.

20. Sakah Kaunda Ying-Jun Zhang J. The Genus Carissa: An Ethnopharmacological, Phytochemical and Pharmacological Review. Natural Products and Bioprospecting [Internet]. 2017 [cited 2019 Feb 18];7(7):181-99. Available from: https://link.springer.com/content/pdf/10.1007\%2Fs13659-017-0123-0.pdf

21. Miyagawa T, Ohtsuki T, Koyano T, Kowithayakorn T, Ishibashi M. Cardenolide glycosides of Thevetia peruviana and triterpenoid saponins of Sapindus emarginatus as TRAIL resistance-overcoming compounds. Journal of Natural Products [Internet]. 2009/07/15. 2009;72(8):1507-11. Available from: https://pubs.acs.org/doi/pdfplus/10.1021/np900202n

22. Malladi S, Ratnakaram VN, Babu KS, Pullaiah T. Phytochemical Screening of Caralluma lasiantha Isolation of C-21 Pregnane Steroid. Oriental Journal of Chemistry [Internet]. 2017;33(2):963-7. Available from: http://www.orientjchem.org/pdf/vol33no2/OJC_Vol33_No2_p_963-967.pdf

23. Koorbanally NA, Mulholland DA, Crouch NR. Isolation of Isovanillin from Aromatic Roots of the Medicinal African Liane, Mondia whitei. Journal of Herbs, Spices \& Medicinal Plants [Internet]. 2000 Dec 18 [cited 2019 Feb 18];7(3):37-43. Available from: http://www.tandfonline.com/doi/abs/10.1300/J044v07n03_05

24. Singh A, Kaur Uppal G. A review on Carissa carandas phytochemistry, ethnopharmacology, and micropropagation as conservation strategy. Vol. 8, Asian Journal of Pharmaceutical and Clinical Research. 2015. 26-30 p. 